\title{
Risk factors of malaria incidence in endemic area of Central Java
}

\author{
Renti Mahkota ${ }^{1}$, Fajaria Nurcandra ${ }^{2}$, Fitria Dewi Puspita Anggraini ${ }^{3}$, Annisa Ika Putri', \\ Bambang Wispriyono ${ }^{4}$ \\ ${ }^{1}$ Department of Epidemiology, Faculty of Public Health, Universitas Indonesia, Indonesia, \\ ${ }^{2}$ Public Health, Faculty of Health Science, Universitas Pembangunan Nasional Veteran \\ Jakarta, Indonesia, ${ }^{3}$ Department of Entomology, Faculty of Medicine, Universitas Gadjah \\ Mada, Indonesia, ${ }^{4}$ Department of Environmental Health, Faculty of Public Health, \\ Universitas Indonesia, Indonesia
}

DOI: http://dx.doi.org/10.19106/JMedScieSup005001201808

\section{ABSTRACT}

Malaria caused 212 million cases worldwide in 2015 , which associated to environmental factors, ecology, and the presence of vectors. Annual paracite incidence (API) in Indonesia in 2011-2015 decreased. Unfortunately, malaria incidence always exist in Purworejo District which known as one of endemic area in Central Java. This research aimed to determine risk factors of malaria incidence in endemic area especially in Purworejo, Central Java. Logistic regression showed that period of residency 19-34 years $(\mathrm{OR}=1.612 ; 95 \% \mathrm{Cl} 0.853-3.046)$, period of residency $>34$ years $(\mathrm{OR}=2.050 ; 95 \%$ $\mathrm{Cl} 1.036-4.060)$, male (OR=2.349; 95\% Cl 1.365-4.043), and education level less than junior high school $(\mathrm{OR}=1.677 ; 95 \% \mathrm{Cl} 0.976-2.882)$ as contributing risk factor to malaria incidence in Purworejo District.

Keywords: malaria incidence - risk factor $=$ endemic area

*corresponding author: renti.mahkota@gmail.com, r-mahkota@ui.ac.id 